\title{
PENINGKATAN HASIL BELAJAR PESERTA DIDIK MELALUI PENERAPAN MODEL PEMBELAJARAN DISCOVERY LEARNING DI KELAS VIII C MTS N 02 KEPAHIANG
}

\author{
Kristian Handayani ${ }^{1 *}$, Yennita ${ }^{1}$, Irdam Idrus ${ }^{1}$, Abas $^{1}$ \\ ${ }^{1}$ Program Studi Pendidikan Biologi, Fakultas Keguruan dan Ilmu Pendidikan, Universitas Bengkulu \\ Email: kristianhandayani97@gmail.com
}

\begin{abstract}
Abstrak
Penelitian ini bertujuan untuk mendeskripsikan hasil belajar kognitif dan psikomotor dengan menerapkan model pembelajaran Discovery Learning di kelas VIIIC MTs N 02 Kepahiang pada materi sistem pernapasan. Jenis penelitian ini adalah penelitian tindakan kelas yang dilakukan dalam dua siklus dengan setiap siklusnya terdiri atas 4 tahapan yaitu: tahap perencanaan, pelaksanaan tindakan, pengamatan dan refleksi. Subyek penelitian ini adalah guru dan seluruh peserta didik kelas VIIIc MTs N 02 Kepahiang. Teknik pengumpulan data dalam penelitian ini yaitu observasi dan tes. Instrumen penelitian yang digunakan adalah lembar observasi dan lembar tes. Hasil analisis data hasil belajar psikomotor pada siklus 1 diperoleh skor rata-rata 12,5 (cukup) dan pada siklus II diperoleh skor rata-rata 15,08 (baik). Kemudian, hasil belajar ranah kognitif pada siklus I mendapatkan persentase sebesar 57,89\%, dan meningkat pada siklus II menjadi 73,68\%. Dari hasil penelitian disimpulkan bahwa model pembelajaran Discovery Learning dapat meningkatkan hasil belajar peserta didik kelas VIIIC MTs N 02 Kepahiang yang dapat dilihat dari peningkatan hasil belajar pada siklus I ke siklus II mengalami kenaikan sebesar $15,79 \%$.
\end{abstract}

Kata Kunci : Aktivitas Guru dan Peserta Didik, Discovery Learning, Hasil Belajar

\begin{abstract}
This study aims to describe cognitive and psychomotor learning outcomes by applying the Discovery Learning model in class VIIIC MTs N 02 Kepahiang in respiratory system material. This type of research is classroom action research conducted in two cycles with each cycle consisting of four stages, namely: the planning stage, implementing actions, observing and reflecting. The subjects of this study were teachers and all students of class VIIIC MTs N 02 Kepahiang. Data collection techniques in this study are observation and tests. The research instruments used were observation sheets and test sheets. The results of the analysis of psychomotor learning outcomes data in cycle 1 obtained an average score of 12.5 (sufficient) and in the second cycle an average score of 15.08 (good) was obtained. Then, cognitive learning outcomes in the first cycle get a percentage of $57.89 \%$, and increase in the second cycle to $73.68 \%$. From the results of the study it was concluded that the Discovery Learning learning model could improve the learning outcomes of class VIIIC students of MTs N 02 Kepahiang which could be seen from the increase in learning outcomes in cycle I to cycle II, an increase of $15.79 \%$.
\end{abstract}

Keywords: Teacher and Student Activities, Discovery Learning, Learning Outcomes 


\section{PENDAHULUAN}

Pendidikan adalah usaha sadar yang dilakukan oleh keluarga, masyarakat, dan pemerintah, melalui kegiatan bimbingan, pengajaran dan/atau latihan, yang berlangsung disekolah dan luar sekolah, untuk mempersiapkan peserta didik agar dapat memainkan peranan dalam berbagai lingkungan hidup secara tepat dimasa yang akan datang (Mudyaharjo, 2006).

Proses Pembelajaran pada satuan pendidikan diselenggarakan secara interaktif, inspiratif, menyenangkan, memotivasi peserta didik untuk berpartisipasi aktif, serta memberikan ruang yang cukup bagi kreativitas dan kemandirian sesuai dengan bakat, minat, dan perkembangan fisik serta psikologis peserta didik (Permendikbud, 2016).

Proses pembelajaran akan menghasilkan hasil belajar, dengan kata lain tercapainya tujuan pembelajaran atau hasil pengajaran itu sangat dipengaruhi oleh bagaimana aktivitas siswa dalam belajar. Pengetahuan hasil proses belajar-mengajar itu bagi siswa seolah-olah telah merupakan bagian kepribadian bagi diri setiap siswa, sehingga akan dapat mempengaruhi pandangan dan cara mendekati suatu permasalahan. Sebab pengetahuan itu dihayati dan penuh makna bagi dirinya (Sardiman, 2014).

Pembelajaran berbasis penemuan atau Discovery Learning mengarahkan peserta didik untuk memahami konsep, arti dan hubungan melalui suatu proses untuk akhirnya sampai kepada suatu kesimpulan. Penemuan konsep tidak disajikan dalam bentuk akhir, tetapi peserta didik didorong untuk mengidentifikasi apa yang ingin diketahui dan dilanjutkan dengan mencari informasi sendiri kemudian mengkoordinasikan atau mengkonstruksi apa yang mereka ketahui dan pahami dalam suatu bentuk akhir. Penggunaan Discovery Learning ingin mengubah kondisi belajar yang pasif menjadi aktif dan kreatif.

Model Discovery Learning menekankan pentingnya pemahaman struktur atau ideide penting terhadap suatu disiplin ilmu melalui keterlibatan aktif mereka sendiri dengan konsep-konsep, prinsip-prinsip dan guru mendorong siswa untuk memiliki pengalaman yang memungkinkan mereka menemukan prinsip untuk diri mereka sendiri (Kadri, 2015).

Berdasarkan hasil observasi dan wawancara dengan guru biologi dikelas VIIIc MTs N 02 Kepahiang terhadap pembelajaran biologi disekolah tersebut, diperoleh informasi sebagai berikut: 1) pembelajaran disekolah sudah menggunakan kurikulum 2013 sebagai acuan dalam proses belajar mengajar; 2) minat belajar siswa masih kurang karena kurang variasinya model pembelajaran yang dilakukan guru sehingga membuat siswa bersifat pasif; 3) guru lebih sering menggunakan metode ceramah sehingga pembelajaran berpusat pada guru saja; 4) dalam proses belajar guru belum menggunakan LKPD dalam pembelajaran dikelas sehingga siswa tidak terlibat aktif dalam proses pembelajaran; 5) hasil belajar peserta didik masih rendah dan dikatakan rendah apabila belum mencapai kriteria ketuntasan minimal (KKM $\geq 65$ ).

Ada beberapa hasil penelitian yang telah menggunakan Discovery Learning sebagai model pembelajaran untuk meningkatkan hasil belajar. Adapun diantaranya penelitian oleh Amyani (2017), menyatakan bahwa dengan penerapan model pembelajaran Discovery Learning dapat meningkatkan hasil belajar siswa di kelas VIII 2 SMP Negeri 03 Kota Bengkulu dengan ketuntasan klasikal $72,5 \%$ menjadi $87,5 \%$. Selanjutnya 
penelitian Rosarina (2016), menyatakan bahwa dengan penerapan model pembelajaran Discovery Learning dapat meningkatkan hasil belajar siswa dengan peningkatan tiap siklusnya yaitu pada siklus | 26,92\%, pada siklus II menjadi $65,38 \%$, dan siklus III 88,46\%.

Berdasarkan latar belakang masalah dan hasil observasi, peneliti berkolaborasi dengan guru IPA terdorong untuk mengambil fokus penelitian dengan judul "Penerapan Model Discovery Learning Pada Materi Sistem Pernapasan Untuk Meningkatkan Hasil Belajar Peserta Didik Kelas VIIIC MTs N 02 Kepahiang" untuk memperbaiki hasil belajar peserta didik yang masih rendah.

\section{METODE}

Jenis penelitian ini adalah Penelitian Tindakan Kelas (PTK). Menurut Uno (2014) penelitian tindakan kelas adalah penelitian yang dilakukan oleh guru didalam kelasnya sendiri melalui refleksi diri. Dengan tujuan untuk memperbaiki kinerjanya sebagai guru sehingga hasil belajar siswa meningkat. Metode yang digunakan pada penelitian ini adalah metode deskriptif. Menurut Sukardi (2016), metode deskiptif merupakan metode penelitian yang berusaha menggambarkan objek atau subjek yang diteliti sesuai dengan apa adanya, dengan tujuan menggambarkan secara sistematis fakta dan karakteristik objek yang diteliti secara tepat.

Subjek dalam penelitian ini adalah guru sebagai peneliti dan seluruh peserta didik kelas VIIIC MTsN 02 Kepahiang yang berjumlah 38 orang peserta didik. Penentuan subyek tersebut secara Convenience Sampling yaitu sampel berdasarkan kemudahan atau ketersediaan individu yang ada dalam suatu kelompok untuk menjadi subjek penelitian (Winarni, 2011).

Teknik pengumpulan data pada penelitian ini yaitu, pengamatan (observation) dan tes (test) hasil belajar. Sedangkan instrumen penelitian yang digunakan yaitu, lembar observasi dan lembar tes.

Data tes hasil belajar kognitif dianalisis dengan menggunakan nilai rata-rata yang diperoleh semua peserta didik dan ketuntasan belajar klasikal peserta didik. Nilai rata-rata yang diperoleh semua peserta didik dan ketuntasan belajar klasikal peserta didik dapat dihitung dengan menggunakan rumus berikut:

1) Rerata dihitung dengan menggunakan rumus sebagai berikut:

$\mathrm{X}=\frac{\Sigma X}{N}$

Keterangan :

$X \quad$ : Nilai rata- rata peserta didik

$\Sigma X \quad$ : Jumlah nilai peserta didik

$\mathrm{N}$ : Jumlah peserta didik

(Arikunto, 2010).

2) Persentase Ketuntasan belajar $K B=\frac{N}{S} \times 100 \%$

Keterangan:

KB : Ketuntasan Belajar Klasikal

$\mathrm{N}$ : Jumlah peserta didik yang mendapat nilai $\geq 65$

$S$ : Jumlah peserta didik

(Arikunto, 2010).

Ketuntasan belajar klasikal di MTs $\mathrm{N} 02$ Kepahiang mata pelajaran IPA Biologi yaitu $70 \%$ dan Kriteria Ketuntasan Minimal (KKM) yaitu $\geq 65$ (Ketentuan MTs N 02 Kepahiang).

Menurut Arikunto (2010), data observasi psikomotor diolah dengan cara:

1. Rata - Rata Skor $=\frac{\text { jumlah skor }}{\text { jumlah } \text { observer }}$ 
2. Skor tertinggi = Jumlah aspek yang diamati $x$ skor tertinggi tiap aspek

3. Skor terendah = Jumlah aspek yang diamati x skor terendah setiap aspek

4. Selisih Skor = Skor tertinggi - skor terendah

5. Kisaran nilai untuk tiap kriteria $=$ jumlah skor

jumlah kriteria penilaian

Lembar observasi psikomotor peserta didik pada siklus I dan siklus II berjumlah 6 butir pengamatan, skor tertinggi tiap butir 3 dan terendah tiap butir 1, maka kategori penelitian untuk lembar observasi psikomotor peserta diidk dapat dilihat pada Tabel 1.

Tabel 1. Kategori Penilaian Psikomotor Peserta Didik Siklus I dan Siklus II

\begin{tabular}{cc}
\hline Rentang Skor & Kategori Penilaian \\
& \\
\hline $6-9$ & Kurang \\
$10-13$ & Cukup \\
$14-18$ & Baik \\
\hline
\end{tabular}

\section{HASIL DAN PEMBAHASAN}

Adapun hasil dari pelaksanaan post test untuk mengukur hasil belajar ranah kognitif peserta didik pada siklus I dan II dapat dilihat pada Gambar 1.

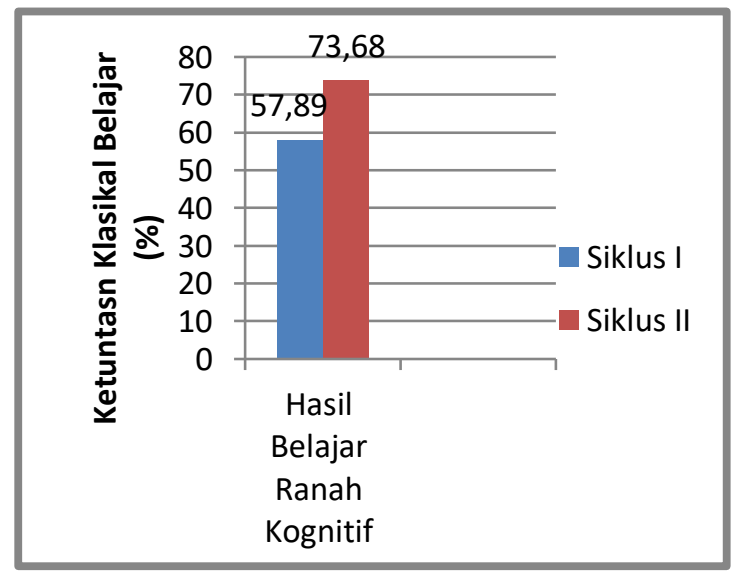

Gambar 1. Diagram Persentase Ketuntasan Klasikal Hasil Belajar Peserta Didik Ranah Kognitif Siklus I dan II
Berdasarkan Gambar 1 tersebut, diketahui bahwa hasil belajar peserta didik ranah kognitif pada siklus I yaitu 57,89\% (belum tuntas), meningkat menjadi 73,68 $\%$ (tuntas) pada siklus II. Kemudian hasil dari pelaksanaan observasi hasil belajar ranah psikomotor menggunakan lembar observasi peserta didik pada siklus I dan II dapat dilihat pada Gambar 2.

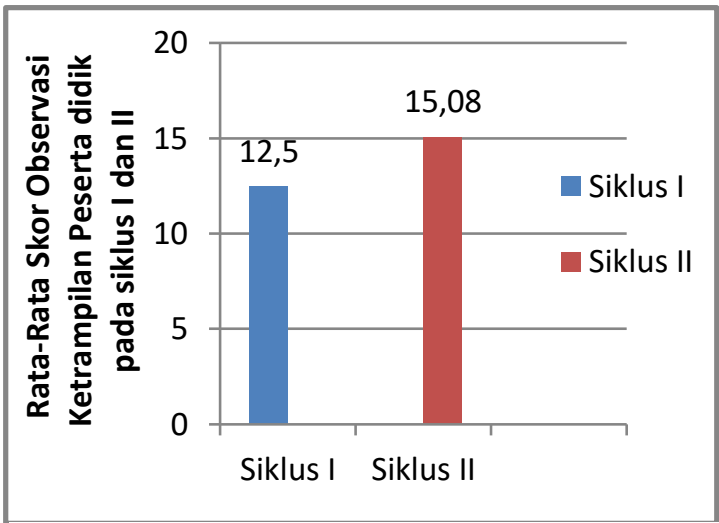

Gambar 2. Diagram Rata-Rata Skor Observasi Psikomotor Peserta Didik pada Siklus I dan II

Berdasarkan analisis data hasil belajar peserta didik ranah kognitif melalui penerapan model pembelajaran Discovery Learning pada materi sistem pernapasan di kelas VIIlc MTs N 02 Kepahiang telah terjadi peningkatan pada kompetensi pengetahuan dari siklus I ke siklus II.

Peningkatan jumlah persentase belajar klasikal siswa dari siklus I ke siklus II menunjukkan bahwa model pembelajaran Discovery Learning dapat meningkatkan hasil belajar kompetensi pengetahuan (kognitif) peserta didik pada materi sistem pernapasan yang di dukung oleh adanya aktivitas guru dan peserta didik yang juga meningkat di siklus II. Hal ini sesuai dengan pendapat Dimyati (2015), yang menyatakan hasil belajar merupakan hasil dari suatu interaksi tindak belajar dan tindak mengajar dan merupakan tujuan akhir 
dilaksanakannya kegiatan pembelajaran di sekolah.

$$
\text { Proses pembelajaran Discovery }
$$
Learning, menurut Novita (2018) memiliki 6 tahapan yaitu:

\section{1) Stimulation (pemberian rangsangan)}

Berdasarkan hasil penelitian, tahap stimulasi ini dijabarkan menjadi dua indikator pengamatan pada aktivitas mengajar guru maupun aktivitas belajar peserta didik. Adapun aktivitas yang dilakukan guru yaitu menampilkan video atau gambar untuk memotivasi peserta didik dan menulis tujuan pembelajaran sedangkan aktivitas peserta didik yaitu menyimak video dan mencatat tujuan pembelajaran yang disampaikan oleh guru. Hal ini didukung oleh pendapat Syah (2005) yang menyatakan bahwa tahap stimulasi berfungsi untuk menyediakan kondisi interaksi belajar yang dapat mengembangkan dan membantu peserta didik dalam mengeksplorasi dan meningkatkan rasa ingin tahu yang tinggi. Rasa ingin tahu inilah nanti yang memotivasi peserta didik untuk terus mengikuti pembelajaran hingga mendapatkan jawaban yang jelas atas pertanyaan yang telah dibuat bersamasama dari kegiatan percobaan.

\section{2) Problem statement (pernyataan/ identifikasi masalah)}

Berdasarkan hasil observasi, aktivitas guru dan peserta didik dalam pernyataan/identifikasi masalah pada siklus I belum optimal dan masih dikategorikan cukup pada aktivitas guru dan cukup pada aktivitas peserta didik. Hal ini dikarenakan pada aktivitas guru hanya mengarahkan 3-4 kelompok peserta didik untuk mengemukakan pendapatnya mengenai pertanyaan penyelidikan yang diberikan. Sehingga, pada aktivitas peserta didik juga hanya 3-4 kelompok yang mengemukakan pendapatnya. Dalam hal ini peserta didik masih bingung dalam dalam proses identifikasi masalah, Karena pada dasarnya siswa yang belum memiliki banyak pengalaman dalam mengidentifikasi masalah jadi akan bingung jika disuruh untuk mengidentifikasi masalah walaupun telah dibantu oleh guru. Hal ini didukung oleh Nasution (2005) yang mengatakan bahwa permasalahan yang bisanya digunakan adalah masalah yang telah ditemukan sebelumnya bukan berdasarkan minat individual.

\section{3) Data collecting (pengumpulan data)}

Pada tahap pengumpulan data ini ada dua indikator pengamatan untuk aktivitas mengajar guru yaitu, menjelaskan prosedur percobaan yang ada pada LKPD dan membimbing peserta didik dalam mengumpulkan data hasil percobaan. Sedangkan aktivitas belajar peserta didik yaitu mendengarkan prosedur percobaan yang disampaikan guru dan mengumpulkan data percobaan. Pada siklus I Kegiatan guru maupun peserta didik masih dikategorikan cukup dan mengalami peningkatan pada siklus II, sehingga kegiatan guru maupun peserta didik pada siklus II telah berkategori baik. Kegiatan pengumpulan data yang menjadi baik ini menandakan bahwa siswa telah mampu mengumpulkan informasi atau data dengan melakukan suatu percobaan. Hal ini juga didukung oleh Dimyati dan Mujiyono (2015) bahwa eksprimen diartikan sebagai keterampilan untuk mengadakan pengujian terhadap ideide yang bersumber dari fakta, konsep dan prinsip ilmu pengetahuan sehingga dapat diperoleh informasi untuk menerima atau menolak ide.

4) Data processing (pengolahan data) 
Pada tahap pengolahan data ada satu indikator pengamatan yaitu membimbing peserta didik dalam mengola data hasil percobaan. Pada siklus I yang dilakukan oleh guru adalah membimbing 3-4 kelompok peserta didik dalam mengelola data hasil percobaan sehingga masuk dalam kriteria cukup yang seharusnya pada tahap ini guru membimbing 5-6 kelompok peserta didik, sedangkan aktivitas belajar peserta didik pada siklus I ini sudah dikategorikan baik karena semua kelompok peserta didik menjawab pertanyaan pada LKPD sesuai dengan materi dan data yang diperoleh. Pada tahap pengolahan data ini dari siklus I ke siklus II siswa sudah dapat menganalisis data yang didapat sebelumnya dengan baik. Hal ini didukung menurut Dimyati dan Mudjiono (2015) menunjukkan bahwa siswa dapat mengkaji lebih lanjut secara kuantitatif maupun kualitataif sebagai dasar pengujian hipotesis dan penyimpulan.

\section{5) Verification (pembuktian)}

Kegiatan yang dilakukan pada tahap ini yaitu guru membimbing peserta didik dalam melakukan verifikasi data hasil percobaan. Pada siklus I guru hanya membimbing 3-4 kelompok peserta didik dalam melakukan verifikasi dengan membandingkan data hasil melalui buku/literatur. Dalam membimbing kelompok ini seharusnya guru membimbing 5-6 kelompok peserta didik dalam melakukan verifikasi. Sedangkan aktivitas yang dilakukan peserta didik pada siklus I ini sudah baik sehingga harus dipertahankan pada siklus II. Sebagai refleksi selanjutnya guru seharusnya membimbing seluruh kelompok dalam melakukan verifikasi/pembuktian. Menurut Permendikbud (2014) Pada tahap verifikasi ini, peserta didik melakukan pemeriksaan secara cermat untuk membuktikan benar atau tidaknya hipotesis yang ditetapkan dengan temuan alternatif, dihubungkan dengan hasil data yang telah diolah. Verifikasi bertujuan bertujuan agar proses belajar akan berjalan dengan baik dan kreatif untuk menemukan suatu konsep, teori, aturan atau pemahaman melalui contoh-contoh yang dijumpai dalam kehidupannya.

6) Generalization (menarik kesimpulan)

Pada tahap ini kegiatan guru adalah membimbing peserta didik untuk membuat kesimpulan. Pada siklus I guru hanya membimbing 3-4 kelompok peserta didik untuk menarik kesimpulan dan hanya 3-4 kelompok peserta didik yang membuat kesimpulan berdasarkan data hasil dan tujuan percobaan pada LKPD karena banyak peserta didik yang masih bingung cara membuat kesimpulan sehinggu guru sibuk menjelaskan pada 3-4 kelompok peserta didik saja. Pada siklus I ini aktivitas guru maupun peserta didik masih dalam kriteria cukup.

Kemudian pada siklus II guru juga hanya membimbing 3-4 kelompok peserta didik dalam menarik kesimpulan dan untuk peserta didik hanya 3-4 kelompok saja yang membuat kesimpulan berdasarkan data hasil dan tujuan percobaan pada LKPD sehingga, pada siklus II aktivitas mengajar guru dan aktivitas belajar peserta didik juga belum optimal. Menurut Dimyati dan Mudjiono (2015), jika siswa telah menemukan atau membuat kesimpulan sendiri berarti siswa tersebut telah dapat memutuskan keadaan suatu objek atau peristiwa berdasarkan fakta, konsep, dan prinsip yang diketahui.

Dengan penerapan model Discovery Learning guru lebih memberikan kesempatan kepada peserta didik untuk aktif dalam kegiatan pembelajaran seperti kegiatan pengumpulan data, pengolahan 
data, dan pembuktian/verifikasi dapat menambah pengetahuan dan keterampilan peserta didik secara simultan. Hal ini didukung juga oleh Sani (2014) bahwa pembelajaran Discovery Learning merupakan model pembelajaran yang menuntut guru lebih kreatif menciptakan situasi yang dapat membuat peserta didik belajar aktif menemukan pengetahuan sendiri. Ini artinya kemampuan siswa dalam ranah kognitif sudah meningkat dan telah tuntas untuk mencapai tujuan pembelajaran yang telah ditetapkan.

Kelebihan dari model Discovery Learning ini antara lain : (1) hasilnya lebih berakar dari pada cara belajar yang lai; (2) lebih mudah dan cepat ditangkap; (3) dapat dimanfaatkan dalam bidang studi lain atau dalm kehidupan sehari-hari; (4) berdaya guna untuk meningkatkan kemampuan siswa menalar dengan baik (Mubarok, 2014).

\section{Dalam Penerapan Discovery} Learning ini siswa lebih aktif untuk membaca dan mencari informasi, pengetahuan serta pemecahan terhadap masalah yang diberikan guru sehingga dengan model tersebut siswa memiliki pengetahuan awal melalui membaca serta ingatan dan pemahaman siswa terhadap materi yang dipelajari jauh lebih lama dibandingkan dengan siswa memperoleh informasi hanya mendengarkan ceramah dari guru (Rismayani, 2013).

Berdasarkan hasil observasi lembar psikomotor peserta didik dengan menerapkan model pembelajaran Discovery Learning pada pembelajaran IPA materi sistem pernapasan di kelas VIIIc MTs N 02 Kepahiang menunjukkan adanya peningkatan dari siklus I ke siklus II hasil observasi lembar psikomotor peserta didik pada siklus I yaitu 12,5 , masih tergolong dalam kriteria cukup. Hal ini dkarenakan ada beberapa indikator pengamatan yang belum dilakukan dengan baik oleh peserta didik seperti kecepatan menyelesaikan praktikum yang masih cukup karena peserta didik menyelesaikan praktikum tepat dengan waktu yang diberikan, seharusnya peserta didik dapat menyelesaikan praktikum lebih cepat dari waktu yang diberikan. Kemudian pada aspek kecepatan dalam menjawab pertanyaan yang masih dalam kriteria kurang dikarenakan peserta didik menjawab pertanyaan melebihi waktu yang diberikan yang juga seharusnya peserta didik mampu menjawab pertanyaan yang diberikan lebih cepat dari waktu yang diberikan. Kemudian pada aspek mengkomunikasikan hasil praktikum dan diskusi, pada aspek ini masih dalam kriteria cukup karena peserta didik dapat mengkomunikasikan hasil praktikum didepan kelas dengan baik namun kurang benar dan terakhir pada aspek menyimpulkan yang masih dalam kriteria kurang, karena peserta didik menyimpulkan hasil diskusi tidak sesuai dengan tujuan pada lembar kerja peserta didik.

Pada siklus II, menunjukkan hasil observasi meningkat sebesar 15,08. Skor dengan rata-rata tersebut telah masuk dalam kriteria baik. Namun, masih ada juga indikator pengamatan yang masih dalam kriteria cukup, yaitu kecepatan menyelesaikan praktikum, karena pada aspek ini peserta didik menyelesaikan praktikum tepat dengan waktu yang telah diberikan yang seharusnya dapat diselesaikan peserta didik lebih cepat dri waktu yang diberikan. Kemudian aspek yang dalam kriteria cukup selanjutnya yaitu dalam menyimpulkan, pada aspek ini peserta didik telah menyimpulkan hasil 
diskusi namun hanya sesuai dengan salah satu tujuan pada LKPD.

Dengan peningkatan aktivitas dan hasil belajar siswa yang terjadi pada hasil penelitian yang telah dilakukan di kelas VIIlc MTs N 02 Kepahiang dengan penerapan model Discovery Learning pada materi sistem pernapasan pada manusia. Terbukti bahwa model Discovery Learning dapat meningkatkan aktivitas dan hasil belajar siswa, hal ini didukung oleh penelitian Serlia (2015) dan Fuspita (2015) dalam Amyani (2017) mengatakan bahwa model Discovery Learning dapat meningkatkan aktivitas guru dan siswa serta hasil belajar siswa selama proses pembelajaran hingga mencapai kriteria tuntas secara klasikal.

\section{PENUTUP}

\section{Simpulan}

Adapun kesimpulan dalam penelitian tindakan kelas ini bahwa Pembelajaran IPA Biologi pada materi sistem pernapasan dengan menerapkan model Dicovery Learning dapat meningkatkan hasil belajar peserta didik kelas VIIIc MTs N 02 Kepahiang pada ranah kognitif (pengetahuan) yaitu dengan ketuntasan belajar klasikal dari 57,89\% di siklus I menjadi $73,68 \%$ di siklus II dan ranah psikomotor (keterampilan) yaitu dari rerata 12,5 disiklus I menjadi 15,08 di siklus II.

\section{Saran}

1) Diharapkan kepada guru mata pelajaran biologi agar dapat menggunakan model Discovery Learning sebagai alternatif dalam meningkatkan hasil belajar peserta didik dengan lebih mengoptimalkan tiap sintaks model pembelajaran Discovery Learning.

2) Diharapkan untuk peneliti selanjutnya memulai pembelajaran hendaknya lebih memperhatikan kondisi peserta didik agar siap sebelum mengikuti pembelajaran sehingga tujuan dari pembelajaran dapat tercapai.

\section{DAFTAR PUSTAKA}

Amyani, E.S., Ansori I., Irawati S. 2017. Penerapan Model Discovery Learning (DL) pada Materi Sistem Ekskresi Manusia Untuk Meningkatkan Aktivitas dan Hasil Belajar Siswa di Kelas $\mathrm{VIII}_{2}$ SMP Negeri 03 Kota Bengkulu. Diklabio: Jurnal Pendidikan Biologi 2(1): 15-20 (online)

(https://ejournal.unib.ac.id/index.ph $\mathrm{p} / \mathrm{jppb} /$ article/view/5137/2696), diakses 22 Juli 2019

Arikunto, Suharsimi. 2010. Dasar-Dasar Evaluasi Pendidikan. Jakarta: Bumi Aksara.

Dimyati dan Mudjiono. 2015. Belajar dan Pembelajaran. Jakarta: Rineka Cipta.

Kadri, Muhammad., Rahmawati M. 2015. Pengaruh Model Pembelajaran Discovery Learning Terhadap Hasil Belajar Siswa Pada Materi Pokok Suhu dan Kalor. Jurnal Ikatan Alumni Fisika Universitas Negeri Medan 1(1): $\quad 30 \quad$ (online) (https://jurnal.unimed.ac.id/2012/in dex.php/jiaf/article/view/2124/pdf), diakses pada 23 Juli 2019

Mudyaharjo, Redja. 2006. Pengantar Pendidikan. Jakarta: PT Raja Grafindo Persada.

Mubarok, Chusni., Sulistyo E. 2014. Penerapan Model Pembelajaran Discovery Learning Terhadap Hasil Belajar Siswa Kelas X TAV Pada Standar Kompetensi Melakukan 
Instalasi Sound System Di SMK Negeri 2 Surabaya. Jurnal Pendidikan Teknik Elektro 3(2): 217 (online) (https://jurnalmahasiswa.unesa.ac.i $\mathrm{d}$ /index.php/jurnal-pendidikanteknik-

elektro/article/view/8495/3923), diakses pada 23 juli 2019

Nasution. 2005. Total Quality Management. Jakarta: PT Gramedia Pustaka Utama

Novita, Fidya., Irawati S., Jumiarni D. 2018. Peningkatan Aktivitas dan Hasil Belajar Melalui Model Discovery Learning Dengan Pendekatan Saintifik. Diklabio : Jurnal Pendidikan Biologi 2(2): 86-93 (online) (https://ejournal.unib.ac.id/index.ph $\mathrm{p} / \mathrm{jppb} /$ article/view/6811/3403), diakses pada 22 Juli 2019

Permendikbud Nomor 58 Tahun 2014 Tentang Kurikulum 2013 Sekolah Menengah Pertama/Madrasah Tsanawiyah. Jakarta: Kementerian Pendidikan Dan Kebudayaan Republik Indonesia (Salinan)

Permendikbud Nomor 22 Tahun 2016 tentang Standar proses Penididikan Dasar dan Menengah (salinan).

Rismayani, Niluh., Sukadi., Pursika I N. 2013. Penerapan Model Pembelajaran Discovery Learning Untuk Meningkatkan Hasil Belajar PKN Siswa. Jurnal Pendidikan Kewarganaan UNDIKSHA 1(2): 7 (online)

(https://ejournal.undiksha.ac.id/inde x.php/JJPP/article/view/405/350), diakses pada 23 Juli 2019

Rosarina, Gina., Sudin A., Sujana A. 2016. Penerapan Model Discovery Learning Untuk Meningkatkan Hasil
Belajar Siswa Pada Materi Perubahan Wujud Benda. Jurnal Pena Ilmiah 1(1): 371 (online) (http://ejournal.upi.edu/index.php/ penailmiah/article/view/3043/pdf), diakses pada 23 Juli 2019

Sani, R.A. 2014. Pembelajaran Saintifik untuk Implementasi Kurikulum 2013. Jakarta: PT Bumi Aksara

Sardiman, A.M.2014. Interaksi dan Motivasi Belajar Mengajar. Jakarta: Rajawali Pers

Sukardi. 2016. Metode penelitian Pendidikan. Jakarta : Bumi Aksara

Syah, Muhibbin. 2005. Psikologi Pendidikan dengan Pendekatan Baru. Bandung: Remaja Rosdakarya.

Uno, Hamzah, dkk. 2014. Menjadi Peneliti PTK yang Profesional. Jakarta: Bumi Aksara

Winarni, Endang Widi. 2011. Penelitian Pendidikan. Bengkulu : FKIP Universitas Bengkulu 